\title{
Deoxyribonucleic Acid Relatedness among Members of the Genus Frankia
}

\author{
M. P. FERNANDEZ,${ }^{1 *}$ H. MEUGNIER, ${ }^{2}$ P. A. D. GRIMONT,${ }^{3}$ AND R. BARDIN ${ }^{1}$ \\ Laboratoire d'Ecologie microbienne, Unité de Recherche Associée au Centre National de la Recherche Scientifique 697, \\ Université Lyon 1, F-69622 Villeurbanne Cedex, France ${ }^{1}$; Centre National des Staphylocoques, Laboratoire de \\ Bacteriologie, Faculté de Médecine Alexis Carrel, F-69372 Lyon Cédex 8, France ${ }^{2}$; and Institut National de la Santé et \\ de la Recherche Médicale Unité 199, Unité des Entérobactéries, Institut Pasteur, F-75724 Paris Cédex 15, France
}

\begin{abstract}
The diversity among 43 isolates of the genus Frankia was studied by determining levels of deoxyribonucleic acid relatedness ( 1 nuclease method) and DNA base compositions. The guanine + cytosine contents ranged from 66 to $75 \mathrm{~mol} \%$. At least nine genomic species were differentiated, including three genomic species among strains compatible with members of the genus Alnus, five genomic species among strains compatible with members of the family Elaeagnaceae, and one genomic species among strains compatible with members of the genus Casuarina. Genomic species 1, which contained proposed type strain CpI1 and nine strains that were compatible with members of the genus Alnus and were 64 to $97 \%$ related to strain ACoN24d, is Frankia alni. Four genomic species contained single strains that were 0 to $30 \%$ related to the other genomic species. Typical strains isolated from members of the genus Casuarina were found to be very homogeneous (69 to $100 \%$ related to strain ORS020606) and clearly separated from atypical strains. The nine genomic species delineated in this study cannot be named since no phenotypic tests are available for identification.
\end{abstract}

The $\mathrm{N}_{2}$-fixing Frankia-actinorhizal plant symbiosis has been reported to occur in more than 194 species of woody dicotyledons belonging to 24 genera and eight diverse families $(4,37)$. The members of the genus Frankia, which was proposed by Becking (7) as the only genus of the family Frankiaceae (Actinomycetales), are recognized primarily on the basis of the symbiotic capacity of the endophytes and their unique morphology in root nodule tissues. Recent studies in which $16 \mathrm{~S}$ ribosomal ribonucleic acid sequencing (17) confirmed morphological similarities (23) led to a proposal to include the genus Geodermatophilus in the Frankiaceae.

Various attempts have been made to delineate groups within the genus Frankia. Since no isolates were available, the first attempt was based on studies of inoculation compatibility groups in which crushed nodule inocula were used. Thus, 10 species were described, with Frankia alni as type species (8). Since the first confirmed isolation by Callaham et al. (12), hundreds of strains have been obtained from various host plants, allowing the use of more accurate methods of characterization. Thus genus Frankia is now relatively well described as a group of symbiotic, filamentous, gram-positive, sporangiaum-forming, vesicule-forming actinomycetes (28). Other characteristics, such as type III cell wall composition (30), type I phospholipids $(29,31)$, deoxyribonucleic acid (DNA) base ratios ranging from 68 to $72 \mathrm{~mol} \%$ (2), and the presence of 2-O-methyl-D-mannose (33), seem to occur commonly in strains of Frankia. Using pure cultures as inocula, Baker (3) redefined the host specificity groups described previously. He found four overlapping groups, which demonstrated the inadequacy of the previous taxonomic system (8). The three major groups contain strains that are compatible with members of the genus Alnus, strains that are compatible with members of the family Elaeagnaceae, and strains that are compatible with members of the genus Casuarina. The first two groups have been separated by various studies in which physiological, immuno-

* Corresponding author. chemical, and genomic characteristics have been used $(1,6$, 41; P. Simonet, P. Normand, A. Hirsh, and A. D. L. Akkermans, in P. M. Gresshoff, ed., The Molecular Biology of Symbiotic Nitrogen Fixation, in press). Few data are available concerning the later group of strains compatible with members of the genus Casuarina due to the small number of strains available.

The low growth rate of strains of Frankia and difficulties in the isolation of high-molecular-weight DNA (Simonet, Normand, Hirsh, and Akkermans, in press) have limited genomic relatedness studies. Using DNA base composition and DNA-DNA hybridization methods, An et al. $(1,2)$ described a genomic group within the strains compatible with members of the genus Alnus and showed a high degree of heterogeneity among the strains compatible with members of the Elaeagnaceae. DNA guanine-plus-cytosine $(G+C)$ contents, the homogeneity of which did not allow An et al. to delineate groups, ranged from 68 to $72 \mathrm{~mol} \%$.

The purpose of this work was to examine the genetic diversity of the genus Frankia by using DNA-DNA hybridization and DNA base composition and a larger spectrum of strains isolated from various geographical areas. As a result, more than nine genomic species were found.

\section{MATERIALS AND METHODS}

Bacterial strains. The sources of the strains of Frankia which we studied are shown in Table 1 . The strains were grown at $28^{\circ} \mathrm{C}$ in $\mathrm{F}$ medium (40) (strains belonging to the Alnus compatibility group), $\mathrm{F}$ medium without Tween 80 (strains belonging to the Elaeagnaceae compatibility group), or BAP medium (34) (strains belonging to the Casuarina compatibility group).

DNA extraction. Previously described methods were used for the extraction (39) and purification (11) of DNA.

Determination of base composition. The chromatographic method of Gehrke et al. (22) was used to determine base composition. Tubes containing $50 \mu \mathrm{g}$ of DNA in $250 \mu \mathrm{l}$ of distilled water were heated at $100^{\circ} \mathrm{C}$ for $5 \mathrm{~min}$ and then plunged into ice. The denatured DNA was then hydrolyzed

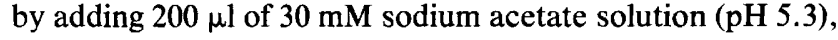


TABLE 1. Origins of strains of Frankia tested

\begin{tabular}{|c|c|c|c|c|c|}
\hline \multicolumn{3}{|c|}{ Strain } & \multirow[b]{2}{*}{ Original host } & \multirow[b]{2}{*}{ Geographic origin } & \multirow[b]{2}{*}{ Reference } \\
\hline Serial no. & Registry no. & $\begin{array}{c}\text { Other } \\
\text { designation }\end{array}$ & & & \\
\hline \multicolumn{6}{|c|}{ Alnus compatibility group } \\
\hline 1 & ULF01010244 & ACoN24d & Alnus cordata & Orléans, France & 38 \\
\hline 2 & ULF0131024083 & $\mathrm{Ar} 24 \mathrm{H} 3$ & Alnus rubra & Orléans, France & Simonet et al. ${ }^{a}$ \\
\hline 3 & ULF0131024152 & Ar24O2 & Alnus rubra & Orléans, France & Simonet et al. $^{a}$ \\
\hline 4 & ULF0107024251 & $\mathrm{Ag} 24_{251}$ & Alnus glutinosa & Orléans, France & Unpublished data \\
\hline 5 & HFP013003 & ArI3 & Alnus rubra & Oregon & 9 \\
\hline 6 & ULQ013202204 & ARgN22d & Alnus rugosa & Québec, Canada & 35 \\
\hline 7 & ULQ0102001007 & $\mathrm{ACN} 1^{A G}$ & Alnus crispa & Québec, Canada & 25 \\
\hline 8 & HFP07010701 & CpI1 & Comptonia peregrina & Massachusetts & 12 \\
\hline 9 & ULF0141016011 & A2J & Alnus viridis & Samoens, France & Unpublished data \\
\hline 10 & ULF014102203 & AV $22 \mathrm{c}$ & Alnus viridis & Lautaret, France & 16 \\
\hline 11 & ULF014101715 & AVN17o & Alnus viridis & La Toussuire, France & Unpublished data \\
\hline 12 & ULF010102340 & $\mathrm{Ac}_{23}$ & Alnus cordata & Saou, France & Unpublished data \\
\hline 13 & ULF011104301 & $\mathrm{AI} 43_{1}$ & Alnus incana & Articol, France & Unpublished data \\
\hline 14 & ULQ0132105009 & $\operatorname{ARgP}^{A G}$ & Alnus rugosa & Québec, Canada & 35 \\
\hline 15 & ULF01070602 & $\mathrm{Mg}{ }_{2}^{A G}$ & Alnus glutinosa & Landes, France & Unpublished data \\
\hline 16 & ULF010102171 & $\mathrm{AcVcl}$ & Alnus cordata & Corsica, France & Unpublished data \\
\hline 17 & UGL010701 & UgAg111b & Alnus glutinosa & Glasgow, Scotland & 43 \\
\hline 18 & UGL010708 & UgAg118b & Alnus glutinosa & Glasgow, Scotland & 43 \\
\hline \multicolumn{6}{|c|}{$\begin{array}{l}\text { Elaeagnaceae compatibility } \\
\text { group }\end{array}$} \\
\hline $19^{\circ-1 / 2}$ & ULF130100112 & $\mathrm{Eal}_{12}$ & Elaeagnus angustifolia & Ecully, France & Unpublished data \\
\hline 20 & ULF130100102 & $\mathrm{Eal}_{2}$ & E. angustifolia & Ecully, France & Unpublished data \\
\hline 21 & ULF130100206 & $\mathrm{Ea} 2_{6}$ & E. angustifolia & Miribel, France & Unpublished data \\
\hline 22 & ULF130100303 & $\mathrm{Ea}_{3}$ & E. angustifolia & St. Bonnet, France & Unpublished data \\
\hline 23 & ULF130100501 & Eacm5 & Soil on $E$. angustifolia & L'Escarène, France & Unpublished data \\
\hline 24 & ULF140102714 & HR27 14 & Hippophaë rhamnoides & Foncouverte, France & Unpublished data \\
\hline 25 & ULQ00231058 & $\mathrm{TX} 31 \mathrm{e}^{H R}$ & Soil on $H$. rhamnoides & Québec, Canada & 10 \\
\hline 26 & ULQ130100144 & EAN1pec & E. angustifolia & Ohio & 26 \\
\hline 27 & ULF140104001 & HRX401a & H. rhamnoides & Ornon, France & 36 \\
\hline 28 & ULQ132500106 & EUN1f & Elaeagnus umbellata & Illinois & 26 \\
\hline 29 & ULF140101801 & HRN18a & H. rhamnoides & Alps, France & 32 \\
\hline 30 & ULF130105001 & $\mathrm{Ea}_{50}$ & E. angustifolia & Mions, France & Unpublished data \\
\hline 31 & ORS060501 & & Colletia spinosissima & Argentina & 21 \\
\hline 32 & GFN140101 & GFN14 & H. rhamnoides & $\begin{array}{l}\text { People's Republic of } \\
\text { China }\end{array}$ & Unpublished data \\
\hline \multicolumn{6}{|c|}{$\begin{array}{l}\text { Casuarinaceae compatibil- } \\
\text { ity group }\end{array}$} \\
\hline 33 & ORS020606 & CeD & Casuarina equisetifolia & Dakar, Senegal & 14 \\
\hline 34 & ORS022602 & & Allocasuarina torulosa & Australia & Nazaret et al. ${ }^{b}$ \\
\hline 35 & ORS020607 & $\mathrm{CeF}$ & Casuarina equisetifolia & Florida & 14 \\
\hline 36 & HFP020203 & $\mathrm{CcI} 3$ & Casuarina cunninghamiana & Florida & 44 \\
\hline 37 & ORS020608 & & Casuarina equisetifolia & Brazil & Nazaret et al. ${ }^{b}$ \\
\hline 38 & HFP022801 & AllI1 & Allocasuarina lehmaniana & Florida & 45 \\
\hline 39 & ORS021001 & $\mathrm{Cj} 1-82$ & Casuarina junghuniana & Thailand & 15 \\
\hline 40 & ORS020609 & & Casuarina equisetifolia & Madagascar & Nazaret et al. ${ }^{b}$ \\
\hline 41 & HFP020202 & $\mathrm{CcI} 2$ & Casuarina cunninghamiana & Florida & 44 \\
\hline 42 & ORS020602 & D11 & Casuarina equisetifolia & Dakar, Senegal & 20 \\
\hline 43 & DDB020110 & & Casuarina sp. & Hawaii & 5 \\
\hline
\end{tabular}

${ }^{a}$ Simonet, Thi Le, Moiroud, and Bardin, in press.

${ }^{b}$ Nazaret et al., in press.

$5 \mu \mathrm{l}$ of $20 \mathrm{mM}$ zinc sulfate, and $10 \mu \mathrm{l}$ of P1 nuclease (Boehringer GmbH, Mannheim, Federal Republic of Germany) and incubating the tubes for $3 \mathrm{~h}$ at $37^{\circ} \mathrm{C}$. The chromatographic system used for the separation and quantitation of nucleotides was the following: $\mathrm{C}_{18}$ reversed-phase column (Société Française de Chromatographie); solvent, $0.6 \mathrm{M}$ $\mathrm{NH}_{4} \mathrm{H}_{2} \mathrm{PO}_{4}$, pH 4.25; flow rate, $1.5 \mathrm{ml} / \mathrm{min}$; absorption measured at $260 \mathrm{~nm}$.

DNA-DNA hybridizations. Native DNA was labeled in vitro by nick translation with tritium-labeled nucleotides (Amersham International, Amersham, England). The procedure used for the hybridization experiments ( $\mathrm{S} 1$ nucleasetrichloroacetic acid method) has been described previously
$(13,24)$. The reassociation temperature was $75^{\circ} \mathrm{C}$. DNADNA hybridization tests were carried out by using labeled DNAs from Frankia spp. strains ACoN24d, AV22c, $\mathrm{ARgP5}^{A G}, \mathrm{Eal}_{12}, \mathrm{TX} 31 \mathrm{e}^{H R}$, EUN1f, HRN18a, Ea50 ${ }_{1}$, and ORS020606 (serial numbers $1,10,14,19,25,28,29,30$, and 33 , respectively) as probes.

Thermal stability of reassociated DNAs. The temperature $\left(T_{m}\right)$ at which $50 \%$ of the reassociated DNA became hydrolyzable by the $\mathrm{S} 1$ nuclease was determined as described previously (13), with slight modifications. After DNA hybridization was completed $\left(16 \mathrm{~h}\right.$ at $\left.75^{\circ} \mathrm{C}\right)$, the hybridization mixture was diluted $1: 2$ (final $\mathrm{NaCl}$ concentration, $0.21 \mathrm{M}$ ) with distilled water to bring the $T_{m}$ below the boiling 
temperature of the mixture. The hybridization mixture was incubated in a glycerol bath, and the temperature was increased in $5^{\circ} \mathrm{C}$ steps from 75 to $105^{\circ} \mathrm{C}$. At each temperature step, a sample was withdrawn, mixed with $\mathrm{S} 1$ buffer, and treated with $\mathrm{S} 1$ nuclease at $60^{\circ} \mathrm{C}$ (24). In addition, a sample withdrawn at $75^{\circ} \mathrm{C}$ was mixed with $\mathrm{S} 1$ buffer without addition of $\mathrm{S} 1$ nuclease. This served to determine the radioactivity of unhydrolyzed DNA (24).

The value called $\Delta T_{m}$ is the difference between the $T_{m}$ of the heteroduplex (in the heterologous reaction) and the $T_{m}$ of the homoduplex (in the homologous reaction).

\section{RESULTS}

The $\mathrm{G}+\mathrm{C}$ contents of the strains ranged from 66.0 to 75 mol\% (Table 2).

Unstandardized reassociation values for homoduplexes ranged from 75 to $100 \%$. The levels of reassociation in control tubes containing only labeled DNAs ranged from 6 to $11 \%$. The $T_{m}$ values for homoduplexes (in $0.2 \mathrm{M} \mathrm{NaCl}$ ) ranged from 83.5 to $96.7^{\circ} \mathrm{C}$.

Of the 43 strains tested, 34 fell into nine discrete DNA relatedness groups (genomic species) (Table 2). The remaining nine strains were not studied further and thus may represent one or more additional groups. Genomic species 1 contained nine strains that were compatible with members of the genus Alnus and were 60 to $97 \%$ related to strain 1, with low levels of divergence $\left(\Delta T_{m}\right.$, less than $\left.3^{\circ} \mathrm{C}\right)$. Four other strains compatible with members of the genus Alnus formed a tight genomic species (genomic species 2) that was more than $80 \%$ related to strain 10 . Genomic species 4 contained six strains that were 69 to $100 \%$ related to strain 19 , with $\Delta T_{m}$ values less than $2.7^{\circ} \mathrm{C}$. Three strains compatible with members of the Elaeagnaceae formed genomic species 5 . These strains were more than $79 \%$ related to strain 25 and yielded low relative binding ratios (less than $49 \%$ ) and high $\Delta T_{m}$ values $\left(7^{\circ} \mathrm{C}\right)$ with genomic species 4 . Genomic species 9 contained eight strains belonging to the Casuarina compatibility group. These strains were 69 to $100 \%$ related to strain 33 , with $\Delta T_{m}$ values less than $4.3^{\circ} \mathrm{C}$.

A total of 13 strains did not belong to any of the genomic species described above. Four of them (strains 14, 28, 29, and 30) were used as sources of reference DNA and were 0 to $30 \%$ related to the five genomic groups described above; thus, these four strains should be considered different genomic species (designated genomic species $3,6,7$, and 8 , respectively). The nine remaining strains were not studied further.

\section{DISCUSSION}

The $\mathrm{G}+\mathrm{C}$ contents of DNAs have been reported to range from 68 to $72 \mathrm{~mol} \%$ in the genus Frankia (2). In this study we found a wider range of $\mathrm{G}+\mathrm{C}$ values, 66 to $75 \mathrm{~mol} \%$. Nevertheless, delineation of groups by using this criterion is not possible. The only exception could be genomic species 5 , which included the strains with the lowest $G+C$ contents.

The single species concept in the genus Frankia is untenable since at least nine genomic species can be delineated. The nine strains which fell into none of the delineated genomic species might represent one or more new genomic species. We did not attempt to resolve all genomic species since the cost and effort are disproportionate with the results when the genomic species contain single strains.

Alnus compatibility group. At least three genomic species were found among the strains compatible with members of the genus Alnus. Genomic species 1 corresponds to genogroup 1 of An et al. (1), which was represented in this study by strains CpI1 and ACN1 ${ }^{A G}$. In Bergey's Manual of Determinative Bacteriology, 8th ed., Becking (8) defined $F$. alni on the basis of its ability to nodulate members of the genus Alnus and Frankia brunchorstii on the basis of its ability to nodulate members of the genera Myrica and Comptonia. This proposal is inconsistent with our results and those of An et al. (1) since strain MpI1 (1) and strain 15 from Myrica sp. and strain 8 from Comptonia sp. fell into genomic species 1. Five strains of genomic species 1 were shown to have the same malate dehydrogenase, peptidase, and 6-phosphogluconate dehydrogenase electromorphs (electromorphs 7,5 , and 4, respectively) (18) and identical protein electrophoretic patterns (19). Lalonde et al. (27) have designated strain CpI1 (strain 8) as the type strain of $F$. alni. We support this proposal, and, as a consequence, our genomic species 1 corresponds to $F$. alni, which is presently the only valid species in the genus (type species).

Genomic species 2, which contained three strains isolated from Alnus species in France, has not been described previously.

Genomic species 3 contained a single strain, strain $\operatorname{ArgP5}^{A G}$, which was found to produce specific malate dehydrogenase, peptidase, and 6-phosphogluconate dehydrogenase electromorphs (electromorphs 2,1 , and 1 , respectively) (18). Our DNA data do not support the proposal of Lalonde et al. (27) that strain ArgP5 ${ }^{A G}$ represents a subspecies of $F$. alni ("Frankia alni subsp. vandijkii") since it was only $2 \%$ related to genomic species 1 .

Among the strains compatible with members of the genus Alnus, neither the original host genus nor the geographical origin seems to be related to the degree of genetic relatedness. For example, French strains isolated from Alnus viridis were expected to be closely related to each other because of the restricted area of the host in the Alps, but one of these strains belongs to genomic species 1 , and the two other strains belong to genomic species 2 . Strains 1,2 , and 3 of genomic species 1 have been isolated from the same alder stand but from different Alnus species. It may be asked whether these strains are really different or whether they represent four isolates of the same strain. These organisms were compared by using different molecular characterization techniques (P. Simonet, N. Thi Le, A. Moiroud, and R. Bardin, Plant Soil, in press) and were shown to be closely related but separable by these methods. Consequently, in this case, host genotype does not seem to take a prominent part in the sorting of the strains from the soil since different Alnus species selected the same Frankia genomic species from the soil. Nevertheless, it remains to be demonstrated whether this result is correlated with a real homogeneity of the Frankia population in this soil. Other explanations could be the better competitivity of this genomic species for nodulation or for growth in pure culture after isolation.

Elaeagnaceae compatibility group. In Bergey's Manual, 8th ed., Becking (8) proposed a single species ("Frankia elaeagnii") for strains that nodulate members of the family Elaeagnaceae (the genera Elaeagnus, Hippophaë, and Shepherdia). Lalonde et al. (27) agreed with this proposal. However, this proposal is not supported by DNA relatedness data. Recent results obtained by using various characterization methods $(1,36,41$; Simonet, Normand, Hirsh, and Akkermans, in press) have indicated that the group of strains compatible with members of the Elaeagnaceae is a highly heterogeneous group. Our results showed that at least two genomic species containing six and three strains and three 
TABLE 2. Levels of DNA relatedness among strains of Frankia species

\begin{tabular}{|c|c|c|c|c|c|c|c|c|c|c|}
\hline \multirow{2}{*}{$\begin{array}{l}\text { Source of unlabeled DNA } \\
\text { (strain) }\end{array}$} & \multirow{2}{*}{$\begin{array}{l}\mathrm{G}+\mathrm{C} \\
\text { content } \\
\text { (mol\%) }\end{array}$} & \multicolumn{9}{|c|}{$\%$ Reassociation at $75^{\circ} \mathrm{C}$ with labeled DNA from: } \\
\hline & & $\begin{array}{c}\text { Strain } \\
1\end{array}$ & $\begin{array}{l}\text { Strain } \\
10\end{array}$ & $\begin{array}{c}\text { Strain } \\
14\end{array}$ & $\begin{array}{l}\text { Strain } \\
19\end{array}$ & $\begin{array}{l}\text { Strain } \\
25\end{array}$ & $\begin{array}{l}\text { Strain } \\
28\end{array}$ & $\begin{array}{l}\text { Strain } \\
29\end{array}$ & $\begin{array}{l}\text { Strain } \\
30\end{array}$ & $\begin{array}{l}\text { Strain } \\
33\end{array}$ \\
\hline \multicolumn{11}{|l|}{ Alnus compatibility group } \\
\hline \multicolumn{11}{|l|}{ Genomic species 1} \\
\hline 1 & 74 & $100^{a}$ & 13 & 22 & 7 & $-{ }^{b}$ & 0 & 6 & 0 & - \\
\hline 2 & 75 & $81(0)^{c}$ & - & - & - & - & 0 & - & - & - \\
\hline 3 & 71 & 97 & - & - & - & - & - & - & - & 3 \\
\hline 4 & 72 & $60(2.7)$ & - & - & - & - & - & - & - & - \\
\hline 5 & 71 & 82 & - & - & - & - & - & - & - & - \\
\hline 6 & - & 77 & - & 32 & - & - & - & - & - & - \\
\hline 7 & 73 & $87(0.5)$ & - & - & - & - & - & - & - & - \\
\hline 8 & 72 & 81 & - & - & - & 8 & 0 & - & - & - \\
\hline 9 & 75 & $64(3)$ & - & 18 & - & - & - & - & - & - \\
\hline \multicolumn{11}{|l|}{ Genomic species 2} \\
\hline 10 & 71 & 1 & 100 & 13 & - & 0 & 0 & - & 0 & 8 \\
\hline 11 & 70 & 2 & 89 & - & - & - & - & - & - & - \\
\hline 12 & 71 & - & 80 & - & - & - & - & - & - & - \\
\hline 13 & 72 & 7 & 110 & 21 & - & - & 0 & - & - & 0 \\
\hline \multicolumn{11}{|l|}{ Genomic species 3} \\
\hline 14 & 70 & 2 & 8 & 100 & 2 & - & - & 0 & - & - \\
\hline \multicolumn{11}{|l|}{ Not yet classified } \\
\hline 15 & - & 53 & - & - & - & - & - & - & - & - \\
\hline 16 & - & 34 & 5 & - & - & - & - & - & - & - \\
\hline 17 & - & 6 & 16 & 11 & - & - & - & - & - & - \\
\hline 18 & 73 & 8 & 33 & 19 & - & - & - & - & - & - \\
\hline \multicolumn{11}{|c|}{ Elaeagnaceae compatibility group } \\
\hline \multicolumn{11}{|c|}{ Genomic species 4} \\
\hline 19 & 70 & - & - & - & 100 & - & 12 & 16 & - & - \\
\hline 20 & 73 & 0 & 0 & - & $71(2.7)$ & - & 0 & - & - & 0 \\
\hline 21 & - & - & - & - & 81 & - & - & - & - & - \\
\hline 22 & 71 & - & - & - & $69(0.7)$ & - & 2 & 20 & - & 0 \\
\hline 23 & 71 & - & - & - & 85 & - & - & - & - & - \\
\hline 24 & 75 & 4 & 6 & - & 103 & - & 2 & 22 & - & 0 \\
\hline \multicolumn{11}{|l|}{ Genomic species 5} \\
\hline 25 & - & - & - & - & - & 100 & - & 0 & - & - \\
\hline 26 & 66 & - & - & - & 38 & 81 & - & - & 0 & - \\
\hline 27 & 67 & - & - & - & $49(7.0)$ & 79 & 0 & 4 & - & - \\
\hline \multicolumn{11}{|l|}{ Genomic species 6} \\
\hline 28 & 70 & $\mathbf{0}$ & - & 0 & - & 4 & 100 & 3 & - & - \\
\hline \multicolumn{11}{|l|}{ Genomic species 7} \\
\hline 29 & 72 & - & - & - & - & - & - & 100 & - & - \\
\hline \multicolumn{11}{|l|}{ Genomic species 8} \\
\hline 30 & - & - & - & - & 19 & - & 12 & 16 & 100 & - \\
\hline Not yet classified & & & & & & & & & & \\
\hline 31 & - & 0 & - & - & - & - & 0 & 0 & - & - \\
\hline 32 & - & - & - & - & 6 & 9 & 1 & 2 & 53 & - \\
\hline Casuarinaceae compatibility g & & & & & & & & & & \\
\hline Genomic species 9 & & & & & & & & & & \\
\hline 33 & 71 & 1 & - & - & - & - & 0 & - & - & 100 \\
\hline 34 & 69 & - & 2 & - & 3 & - & - & 1 & 0 & 83 \\
\hline 35 & - & - & - & - & - & - & - & - & - & 87 \\
\hline 36 & 69 & - & - & - & - & - & - & - & - & 107 \\
\hline 37 & 70 & - & - & 0 & - & 0 & - & - & - & 88 \\
\hline 38 & 70 & - & - & - & - & - & - & - & - & 80 \\
\hline 39 & 69 & - & - & - & - & - & - & 0 & - & $79(4.3)$ \\
\hline 40 & 70 & - & - & - & - & - & - & - & - & $69(3)$ \\
\hline Not yet classified & & & & & & & & & & \\
\hline 41 & 71 & - & - & - & 0 & - & - & 0 & - & $38(10)$ \\
\hline 42 & 72 & - & 0 & - & 0 & - & - & 0 & - & 0 \\
\hline 43 & 73 & - & - & - & 30 & - & 0 & 8 & - & 0 \\
\hline
\end{tabular}

${ }^{a}$ Level of relatedness of $75^{\circ} \mathrm{C}$.

b - No data.

${ }^{c}$ The numbers in parentheses are $\Delta T_{m}$ values (in degrees Celsius).

other genomic species containing single strains can be differentiated. Our experimental work was finished when Lalonde et al. (27) proposed a type strain for " $F$. elaeagnii.", Since this strain was not included in our study, we have no way of knowing which of our genomic species (if any) corresponds to " $F$. elaeagnii." As observed for the Alnus compatibility group, there is no correlation between the original host genus and the DNA homology groups. This 
result agrees with the cross-inoculation tests of Baker (3), which showed that Elaeagnus angustifolia and Hippophä rhamnoides have exactly the same compatible strain spectrum. Genomic species seem to be more directly related to geographical origin. Strains from genomic species 4 were all isolated from France, whereas strains 25 and 26, in genomic species 5, were isolated from Canada and the United States. The close genomic relationship between strains 25 and 26 could be expected because of their identical isoenzyme and protein patterns $(18,19)$. Similarly, strain 28 , which is markedly different from the other strains as determined by these two methods, was found in this study to constitute a separate DNA homology group. The very low level of genetic relatedness between strains 28 and 29 is in agreement with the results of a previous study conducted with nif gene restriction fragment length polymorphisms (Simonet, Normand, Hirsh, and Akkermans, in press).

Casuarina compatibility group. In Bergey's Manual, 8th ed., Becking (8) proposed the single species Frankia casuarinae for symbionts of Casuarina species. Since this proposal, most of the taxonomic studies of strains of Frankia have not taken into account strains that are compatible with members of the Casuarinaceae; thus, few data exist about them. Cross-inoculation tests with pure cultures isolated from Casuarina species nodules have shown that at least two groups can be distinguished. Some of these isolates are able to renodulate their original host plants and are called typical strains. The other isolates are not able to renodulate their original hosts but can infect plants belonging to the Elaeagnaceae; these are called atypical strains. In this study, eight typical strains and three atypical strains were tested. Our results showed that the eight typical strains are closely related to each other and constitute a single DNA homology group. Although few strains have been tested, they should be representative of strains compatible with members of the genus Casuarina because of their widely diverse origin (Table 1). This homogeneity could be explained by the fact that all casuarinas originate from Australia and the South Pacific Islands and have been disseminated worldwide (44). The homogeneity of this group has also been demonstrated by nif gene restriction fragment length polymorphisms, which separated the typical group from the atypical group (S. Nazaret, P. Simonet, P. Normand, and R. Bardin, Plant Soil, in press). The three atypical strains do not belong to the same DNA homology group, confirming the wide differences reported when nif gene restriction fragment length polymorphism patterns were used (Nazaret et al., in press). Several hypotheses have been proposed concerning the heterogeneity of atypical strains and their strong divergence from the typical group. Presently, these organisms are generally considered to be co-infective strains that are present in nodules with typical strains. The position of strain 41 is not clear; it was $38 \%$ related to genomic species 9 (Table 2), had the same isoenzyme pattern as three typical strains (data not published), and was very similar to the typical group strains when nif gene restriction fragment length polymorphism patterns were used (Nazaret et al., in press).

The taxonomic position of the strains of Frankia isolated from members of the genus Myrica should be of major interest since these strains are compatible with host genera belonging to the three major inoculation groups (3) (Alnus, Elaeagnaceae, and Casuarina compatibility groups). Generally, strains from this group are not easy to isolate, and their growth rates are slow. In this study only strain 15 originated from a member of the genus Myrica (obtained from Alnus glutinosa inoculated with crushed nodules from Myrica gale). This organism was $53 \%$ related to genomic species 1 , but the poor efficiency of DNA extraction for this strain did not allow us to confirm this intermediate result with a $\Delta T_{m}$ study.

It should be noted that the available isolates of Frankia are certainly not representative of the real diversity within the genus Frankia. For example, in this study we took into account only 7 of the 35 Alnus species. Moreover, isolation attempts have remained unsuccessful with a number of host plants, and few methods are available to perform isolation of non-nodulating (saprophytic) strains of Frankia species from the soil. Therefore, a major bias is introduced in the subsampling. A bacterial species is now defined as a DNA relatedness group (genomic species) which can be identified by phenotypic tests (42). Among the nine genomic species of the genus Frankia, genomic species 1 is $F$. alni. Unfortunately, the phenotypic data available are not comprehensive enough to separate these genomic species. In accordance with the recommendations published by a group of experts (42), these genomic species cannot be named at this time.

\section{ACKNOWLEDGMENTS}

We thank F. Grimont and J. Freney for professional advice, A. Moiroud for strains, and J. Haurat and E. Ageron for technical assistance.

\section{LITERATURE CITED}

1. An, C. S., W. S. Riggsby, and B. C. Mullin. 1985. Relationships of Frankia isolates based on deoxyribonucleic acid homology studies. Int. J. Syst. Bacteriol. 35:140-146.

2. An, C. S., J. H. Wills, W. S. Riggsby, and B. C. Mullin. 1983. Deoxyribonucleic acid base composition of 12 Frankia isolates. Can. J. Bot. 61:2859-2862.

3. Baker, D. D. 1987. Relationships among pure cultured strains of Frankia based on host specificity. Physiol. Plant. 70:245-248.

4. Baker, D. D. 1988. Opportunities for autoecological studies of Frankia, a symbiotic actinomycete, p. 271-276. In Y. Okami, T. Beppu, and H. Ogawara (ed.), Biology of actinomycetes ' 88 . Japan Scientific Society Press, Tokyo.

5. Baker, D. D., and D. O'Keefe. 1984. A modified sucrose fractionation procedure for the isolation of frankiae from actinorhizal root nodules and soil samples. Plant Soil 78:23-28.

6. Baker, D. D., W. L. Pengelly, and J. G. Torrey. 1981. Immunochemical analysis of relationships among isolates of frankiae (Actinomycetales). Int. J. Syst. Bacteriol. 31:138-151.

7. Becking, J. H. 1970. Frankiaceae fam. nov. (Actinomycetales) with one new combination and six new species of the genus Frankia Brunchorst 1886, 174. Int. J. Syst. Bacteriol. 20: 201-220.

8. Becking, J. H. 1974. Family III. Frankiaceae Becking 1970, 201, p. 701-706. In R. E. Buchanan and N. E. Gibbons (ed.), Bergey's manual of determinative bacteriology, 8th ed. The Williams \& Wilkins Co., Baltimore.

9. Berry, A., and J. G. Torrey. 1979. Isolation and characterization in vivo and in vitro of an actinomycetous endophyte from Alnus rubra Bong, p. 69-83. In J. C. Gordon, C. T. Wheeler, and D. A. Perry (ed.), Symbiotic nitrogen fixation in the management of temperate forests. Forest Research Laboratory, Oregon State University, Corvallis.

10. Bertrand, L. J., and M. Lalonde. 1985. In vitro propagation and nodulation by Frankia of actinorhizal Russian olive (Elaeagnus angustifolia L.). Plant Soil 87:143-152.

11. Brenner, D. J., A. C. McWorter, J. K. Leete Knutson, and A. G. Steigerwalt. 1982. Escherichia vulneris: a new species of Enterobacteriaceae associated with human wounds. J. Clin. Microbiol. 15:1133-1140.

12. Callaham, D., P. Del Tridici, and J. G. Torrey. 1978. Isolation and cultivation in vitro of the actinomycete causing root nodulation in Comptonia. Science 199:899-902.

13. Crosa, J. M., D. J. Brenner, and S. Falkow. 1973. Use of a 
single-strand specific nuclease for analysis of bacterial and plasmid deoxyribonucleic acid homo- and heteroduplexes. $\mathbf{J}$. Bacteriol. 115:904-911.

14. Diem, H. G., and Y. Dommergues. 1983. The isolation of Frankia from nodules of Casuarina. Can. J. Bot. 61:2815-2821.

15. Diem, H. G., D. Gauthier, and Y. Dommergues. 1983. An effective strain of Frankia from Casuarina sp. Can. J. Bot. 61:2815-2821.

16. Faure-Reynaud, M., M. A. Bonnefoy-Poirier, and A. Moiroud. 1986. Influence de $\mathrm{pH}$ acides sur la viabilité et l'infectivité d'isolats de Frankia. Plant Soil 96:347-358.

17. Fox, G. E., and E. Stackebrandt. 1987. The application of $16 \mathrm{~S}$ rRNA cataloging and 5S rRNA sequences in bacterial systematics, p. 405-458. In R. R. Colwell and R. Grigorova (ed.), Methods in microbiology. Academic Press, Inc. (London), Ltd., London.

18. Gardes, M., J. Bousquet, and M. Lalonde. 1987. Isozyme variation among 40 Frankia strains. Appl. Environ. Microbiol. 53:1596-1603.

19. Gardes, M., and M. Lalonde. 1987. Identification and subgrouping of Frankia strains using sodium dodecyl sulfate-polyacrylamide gel electrophoresis. Physiol. Plant. 70:237-244.

20. Gauthier, D., H. G. Diem, and Y. Dommergues. 1981. Infectivité et effectivité des souches de Frankia isolées de nodules de Casuarina equisetifolia et d'Hippophae rhamnoides. C. R. Acad. Sci. 293:489-491.

21. Gauthier, D., L. Frioni, H. G. Diem, and Y. Dommergues. 1984. The Colletia spinosissima-Frankia symbiosis. Oecol. Plant. 5:231-239.

22. Gehrke, C. W., R. A. McCune, M. A. Gama Soao, M. Ehrlich, and K. C. Kuo. 1984. Quantitative reverse-phase high-performance liquid chromatography of major and modified nucleosides in DNA. J. Chromatogr. 301:199-219.

23. Goodfellow, M., and T. Cross. 1984. Classification, p. 7-164. In M. Goodfellow, M. Modarski, and S. T. Williams (ed.), The biology of the actinomycetes. Academic Press, Inc. (London), Ltd., London.

24. Grimont, P. A. D., M. Y. Popoff, F. Grimont, C. Coynault, and M. Lemelin. 1980. Reproducibility and correlation study of three deoxyribonucleic acid hybridization procedures. Curr. Microbiol. 4:325-330.

25. Lalonde, M. 1979. Techniques and observations of the nitrogenfixing Alnus root nodule symbiosis, p. 421-434. In N. S. Subba Rao (ed.), Recent advances in biological nitrogen fixation. Oxford and IDH Publications, New Delhi, India.

26. Lalonde, M., H. E. Calvert, and S. Pine. 1981. Isolation and use of Frankia strains in actinorhizae formation, p. 296-299. In A. H. Gibson and W. E. Newton (ed.), Current perspectives in nitrogen fixation. Australian Academy of Science, Canberra.

27. Lalonde, M., L. Simont, J. Bousquet, and A. Séguin. 1988. Advances in the taxonomy of Frankia: recognition of species alni and elaeagni and novel subspecies pommerii and vandijkii, p. 671-680. In H. Bothe, F. J. de Bruijn, and W. E. Newton (ed.), Nitrogen fixation: hundred years after. Gustav Fisher, Stuttgart.

28. Lechevalier, M. P. The taxonomy of the genus Frankia. Plant Soil 78:1-6.
29. Lechevalier, M. P., F. Horrière, and H. Lechevalier. 1982. The biology of Frankia and related organisms. Dev. Ind. Microbiol. 23:51-60.

30. Lechevalier, M. P., and H. A. Lechevalier. 1979. The taxonomic position of the actinomycetic endophytes, p. 111-122. In J. C. Gordon, C. T. Wheeler, and D. A. Perry (ed.), Symbiotic nitrogen fixation in the management of temperate forests. Forest Research Laboratory, Oregon State University, Corvallis.

31. Lopez, M. F., C. S. Whaling, and J. G. Torrey. 1983. The polar lipids and free sugars of Frankia in culture. Can. J. Bot. 61:2834-2842.

32. Moiroud, A., and M. Faure-Reynaud. 1983. Influence de quelques herbicides à large spectre sur la croissance et l'infectivité de cultures pures de Frankia. Plant Soil 74:133-136.

33. Mort, A., P. Normand, and M. Lalonde. 1983. 2-O-methylD-mannose, a key sugar in the taxonomy of Frankia. Can. J. Microbiol. 29:993-1002.

34. Murry, M. A., M. S. Fontaine, and J. G. Torrey. 1984. Growth kinetics and nitrogenase induction in Frankia sp. HFP ArI3 grown in batch culture. Plant Soil 78:61-78.

35. Normand, P., and M. Lalonde. 1986. The genetics of actinorhizal Frankia: a review. Plant Soil 90:429-453.

36. Normand, P., P. Simonet, and R. Bardin. 1988. Conservation of nif sequences in Frankia. Mol. Gen. Genet. 213:238-246.

37. Silvester, W. B., O. Balboa, and J. A. Martinez. 1985. Nodulation and nitrogen fixation in members of the Rhamnaceae (Colletia, Retanilla, Talguenea and Trevoa) growing in the Chilean matorral. Symbiosis 1:29-38.

38. Simonet, P., A. Capellano, E. Navarro, R. Bardin, and A. Moiroud. 1984. An improved method for lysis of Frankia with achromopeptidase allows detection of new plasmids. Can. J. Microbiol. 30:1292-1295.

39. Simonet, P., J. Haurat, P. Normand, R. Bardin, and A. Moiroud. 1986. Localisation of nif genes on a large plasmid in Frankia sp. strain ULQ0132105009. Mol. Gen. Genet. 204:492-495.

40. Simonet, P., P. Normand, A. Moiroud, and M. Lalonde. 1985. Restriction enzyme digestion patterns of Frankia plasmids. Plant Soil 87:49-60.

41. St. Laurent, L., J. Bousquet, L. Simon, and M. Lalonde. 1987. Separation of various Frankia strains in the Alnus and Elaeagnus host specificity groups using sugar analysis. Can. J. Microbiol. 33:764-772.

42. Wayne, L. G., D. J. Brenner, R. R. Colwell, P. A. D. Grimont, O. Kandler, M. I. Krichevsky, L. H. Moore, W. E. C. Moore, R. G. E. Murray, E. Stackebrandt, M. P. Starr, and H. G. Trüper. 1987. Report of the Ad Hoc Committee on Reconciliation of Approaches to Bacterial Systematics. Int. J. Syst. Bacteriol. 37:463-464.

43. Wheeler, C. T., J. E. Hooker, A. Crowe, and A. M. M. Berrie. 1986. The improvement and utilization in forestry of nitrogen fixation by actinorhizal plants with special reference to Alnus in Scotland. Plant Soil 90:393-406.

44. Zhang, Z., M. F. Lopez, and J. G. Torrey. 1984. A comparison of cultural characteristics and infectivity of Frankia isolates from root nodules of Casuarina species. Plant Soil 78:79-90.

45. Zhang, Z., and J. G. Torrey. 1985. Studies of an effective strain of Frankia from Allocasuarina lehmaniana of the Casuarinaceae. Plant Soil 87:1-16. 